\title{
An Affecting of Community-Based Tourism Toward Integrated Sustainable Homestay in Malaysia
}

\author{
${ }^{1}$ Muhammad Abi Sofian Abdul Halim, ${ }^{2}$ Aziz Amin, ${ }^{1}$ Mohd Shaladdin Muda \\ ${ }^{1}$ School of Buiness and Maritime Management, \\ Universiti Malaysia Terengganu, \\ Kuala Terengganu, Terengganu, MLAYSIA \\ Tel: 6013-9204322 \\ ${ }^{2}$ Faculty of Applied Social Science \\ Universiti Sultan Zainal Mohd Abidin, \\ Kuala Terengganu, Terengganu, MALAYSIA \\ Tel: 6019-9885293
}

\begin{abstract}
In Malaysia, a Model of Community Based Tourism that has been discussed by a numbers of scholars becomes a significant role to the homestay industry that operated by community in a rural area. In depth, this model took account various resources and stakeholders in order to integrate the sustainability of rural homestay development. However, a number of rural homestay operators are lacking of knowledge toward the crucial of integrated sustainable model as well as practicing in their business. Thus, the objective of this paper is to study the model of community-based tourism as an influencing factor that affecting to the integrated sustainable homestay which are operating in Malaysia rural areas. The results of multiple regressions analysis indicate that the only factors of socio-economy, organizational culture and government are support significantly affecting to the integrated sustainable homestay. Generally, the results indicated that most of homestay operators are not really satisfying the important factors of community-based tourism that affecting to their integrated sustainable homestay. Therefore, the concept and model of Community-based Tourism become crucial applicable in developing an awareness among rural homestay operators toward the integrated of homestay sustainability.
\end{abstract}

Keywords- Integrated sustainability homestay, Integrated Rural Tourism, Homestay, rural tourism, Community Based Tourism

\section{Introduction}

Nowadays, the tourism industry is a rapid growing industry and contributes to the economic enhancement as well as development of a country. In particular, World Tourism Organization (UNWTO) has mentioned that tourism industry considered as a fundamental contributor towards economy recovery by generation billions of dollars in exports and creating millions jobs. In 2015, UNWTO forecasts international tourist arrivals to grow between $3 \%$ and $4 \%$ and growth is expected to be stronger in Asia and the Pacific and followed by the other regions. Tourism industry development is a high priority agenda for nations and communities everywhere. Thus, it is essentially an economic endeavor which generates social capital as a competitive advantage (Brida et al., 2010).
Malaysia is a country situated in the Southeast Asia that blessed with many attractive environmental atmosphere and traditional culture heritages which has been existence for thousands of years. These integrated of social-economic, environment and unique of culture are synonym with the characters of the current tourism product preferred by both local and foreign tourists. In order to sustain the demand of domestic tourist products, Malaysian government has taken several actions on policy to ensure the continuation of promotional plan for these tourism products in the future as well as to move in the right tract. Currently, tourism Malaysia set a national mission to achieve the National Key Economic Areas goal of 36 million tourist arrivals and RM168 billion in tourist receipts by 2020 (Tourism Malaysia, 2014). Consequently, the Malaysian homestay industry is part of community based tourism that contributed to the Malaysia gross domestic product. However, a number of communities that involved in homestay industry in Malaysia are lacking of knowledge and experience toward the proper operating in their business. In fact, some of them are not satisfying the various external factors that affecting to their business, such as; their community cooperation, government support, and environmental factors. As supporting to this statement, previous studied has stated that a numbers of influencing factors that have to considered as affecting to the integrated sustainable homestay such as; local leadership, government support, organizational culture, branding, environment, socio-economic, organizational capability and community participation (Cawley \& Gillmor, 2008; Saxena, 2007; Mitchell \& Eagles, 2001; Cawley and Gilmor, 2008). Thus, objective of this paper endeavors to measure the relationship of influencing factors affecting the integrated sustainable homestay in Malaysia.

\section{Malaysia Tourism Industry}

Malaysia tourism industry started from the early 1970s and has become the second highest foreign exchange earner for the country after the manufacturing sector (National Malaysian Plan, 2004). However, Yusof et al. (2010) stated that tourism industry was not regarded as an important 
economic activity in Malaysia up until the 1970s; otherwise recently the tourism sector has ranked second in generating foreign exchange after the oil and gas industry. In the early growth of Malaysia tourism industry, there was more focused destination at beach resorts for relaxation. In 1990s it was extended the attractive activities to include shopping, events, theme park and nature-based. As such, Malaysia had increased the tourism promotions, arranged various programs and events, as well as diversified and upgraded the tourism-related facilities. Fortunately, the World Travel \& Tourism Council (WTTC), declared Malaysia as a destination full of unrealized potential with the main strength as the availability of a vast range of diverse attractions to suit all tastes and relatively affordable prices.

Therefore, to encourage tourism expansion and development towards a greater sustainability, Malaysia Government has allocated RM 316 million for tourism industry. The successful initiatives to promote Visit Malaysia 2014 campaign has lead Ministry of Tourism and Culture to designated year 2015 as Malaysia Year of Festival. Thus, it will be great opportunity for Malaysia with multicultural society, historical background and attractions to promote Community Based Tourism especially for homestay programs which offer tourist to interact, gain knowledge, and experience the life style and culture of the host family as well as the local community. In addition, Malaysia's strong positioning as the 10th Most Visited Country in the world in 2012, 2nd Most Visited Country in Asia Pacific and listing by Lonely Planet as one of the top 10 destinations to visit in 2014 are all factors that will increase tourist arrival in year 2015 (Tourism Malaysia, 2014)

Nowadays, the Malaysia homestay industry become demanding among the foreign tourist as well as to reside, have meals and be entertained by the cultural performances and traditional activities of the host and participating villagers (Aminudin and Jamal, 2006). Malaysian homestay is a type of community based tourism that employs a somewhat different concept than homestay tourism in other region. Lynch, McIntosh and Tucker (2009) characterized homestay as the buying and selling of more than "just a bed" where the host would consider hosting as a lifestyle choice. The term "home-stay" refers to utilizing privately owned residential housings in conjunction with local humanities, natural landscapes, environmental resources, as well as agricultural, forestry, fishing, and hunting industries to provide travelers with a place to stay in the country (Chang, Jiang \& Lan, 2009).

\section{The Concept of Community Based Tourism}

Community Based Tourism can be delineated as a form of tourism 'where the local community has substantial control over, and involvement in, its development and management, and a major proportion of the benefits remains within the community (Razzaq et al., 2013). Community based tourism is a form of rural tourism that has increasingly been accepted in most developing countries as a strategy towards poverty reduction (Goodwin, 2006). According to Murphy (1985), the concept of Community Based Tourism has emerged in response to the negative impact of mass tourism that took place during the early stages of tourism development; particularly towards local people. Attributable to the potential of Community Based Tourism towards community development, many rural communities have turned to tourism as a way of diversifying their economy activities (Briedenhann \& Wickens, 2004; Mair, 2006). Community-based tourism (CBT) is promoted as a strategy to foster community development in developing countries, as a means of both poverty reduction and community development. CBT is also 'gaining popularity' in fostering positive environmental and social impacts (Baktygulov \& Raeva, 2010).

\section{Literature Review}

Previous studied has stated that an integrated approach to rural tourism is increasingly important in line with developments of tourism sector worldwide. But now, an integrated rural tourism has various interpretations and dimensions according to different situations. In general, Integrated Rural Tourism can be defined as the potential of tourism to preserve the rural environment and as tourism that is explicitly related to the economic, social, cultural, natural and human structures of the environment where it is developed. In practical terms, it refers to tourism that has clear connections to local resources, products and inhabitants (Jenkins \& Oliver, 2001; Oliver \& Jenkins, 2003; Saxena et al., 2007). According to Cawley \& Gillmor (2008), the objective of integrated rural tourism is to promote environmental, economic, and socio cultural sustainability in tourism and to empower local people, given that the decision and action power stems from the inhabitants of the area

The interdependence of components in Integrated Rural Tourism is multi-dimensional, intended to promote the development of tourism on the strength of local resources, such as; historical, cultural, landscape-based, and the interplay between individual personalities and networks of exchange. Hence, the destination's specificities are able to compete globally (Saxena \& Ilbery, 2010). Saxena (2007) has stated that sholars has been proposed the framework of Integrated Rural Tourism to overcome the problems between rural tourism, rurality and tourism.

In changing the trends in tourism demand, the notion of Integrated Rural Tourism is intended to open up practical ways of thinking about improving linkages between tourism and local and regional resources, activities, products and communities (Saxena, Clark, Oliver \& Ilbery, 2007). The notion of integration provides a means of thinking about ways of bringing diverse actors, networks and resources together more successfully into networks of cooperation and collaboration (Saxena, 2005). Fundamentally, Integrated Rural Tourism concept aim to capture the type of tourism that elevates link with economic, social, cultural, natural and human resources in the localities where rural tourism activities take place. However, the absence of an integrative framework for managing this diversity of stakeholders and 
structures has been identified as a weakness in developing the rural tourism. (Mitchell \& Eagles, 2001). Therefore, developing model of Integrated Rural Tourism will enhance rural tourism that contains various stakeholders such as tour operators, business owner, host community members and agencies.

The proposed Model of Integrated Rural Tourism is adapted from Saxena (2007) are constructed by seven different dimensions: networking; scale; endogeneity; sustainability; embeddedness; complementarity; and empowerment. The dimension of networking, embeddedness and empowerment are in relationship to promote local participation in managing cultural and economic resources. This model emphasize that these seven dimension will centralize the role of local actors and communities in rural transformations by highlighting the local needs, benefits and control in rural development. Perhaps, this model will be useful to integrate into local rural settings without compromising the rural characteristics of the environment, communities and ways of living (Saarinen \& Lenao, 2014).

Besides that, the conceptual Model of Integrated Rural Tourism also adopted from (Cawley and Gilmor, 2008) model. They suggest seven features as being characteristic of integration in the domain of rural tourism: an ethos of promoting multidimensional sustainability, the empowerment of local people, endogenous ownership and resource use, complementarity to other economic sector and activities, appropriate scale of development, networking among stakeholder and embeddedness in local system. When dealing with rural tourism development, the real challenges is to balance the various priorities in appropriate way because it involve with various stakeholders. Cawley and Gilmor (2008) emphasized that this model will be useful to be operated to various level of stakeholder in the industry. Effective networking and appropriate local embeddedness will be instrumental to achieve the overall strategy of sustainability.

\section{Hypothesis and Theoretical Framework}

The main objective of this paper is to study the influencing factors and affecting on the integrated sustainable homestay in Malaysia. Based on literature study, researchers have divided influencing factors into eight hypothesis, there are;

H1: There is a significant relation-ship between socioeconomy and integrated sustainable homestay in Malaysia

$\mathrm{H} 2$ There is a significant relation-ship between local leadership and integrated sustainable homestay in Malaysia

H3: There is a significant relation-ship between Community participation and integrated sustainable homestay in Malaysia

H4: There is a significant relation-ship between environment and integrated sustainable homestay in Malaysia

H5: There is a significant relation-ship between branding and integrated sustainable homestay in Malaysia

H6: There is a significant relation-ship between organization culture and integrated sustainable homestay in Malaysia

H7: There is a significant relation-ship between government support and integrated sustainable homestay in Malaysia

As well as to visualized the hypothesis in this study, the conceptual framework has been developed based on the model Cawley M \& Gillmor DA (2007) as modified from the original model by Jengkens $\mathrm{T}$ and Olver (2001). This model consists of indicators such as local leadership, government support, organizational culture, branding, environment, socio-economic, organizational capability and community participation.

Figure 1: Conceptual Framework

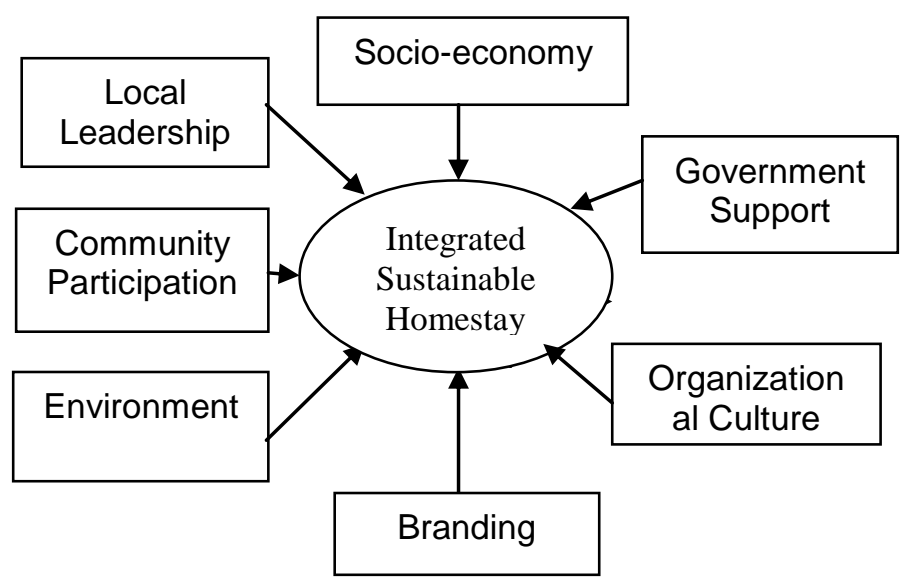

\section{Methodology}

Since this study is aimed at addressing the community based tourism as an influencing factors that affecting to the integrated sustainable homestay among practitioners in Malaysia homestay industry, a quantitative approach was used through distributed questionnaire to the respondents. As set of questionnaire was used as the main instruments in the data collection process adopted so that investigating the variables was made possible. First part of questionnaire is contained of demographic items, furthermore, the factor of organizational culture become as a second part of questionnaire and follow by the government support, local leadership, community participation, organizational capability, socio-economic, environment, and branding. As well as literature is concerned, there are numbers of items has been constructed for each variables based on indicators. Then, a sample of 60 homestay operators in rural area was chose to answer the questionnaires.

Furthermore, the data was analyzed using the Multiple Regression Analysis to determine the relationship between the communities based tourism which include organizational culture, government support, local leadership, community participation, organizational capability, socio-economic, environment, and branding toward the integrated sustainable homestay in Malaysia. 


\section{Analysis and Finding}

In order to identify the significance relationship between influencing factors toward the integrated sustainable homestay, multiple regressions were used to test the $\mathrm{H} 1, \mathrm{H} 2$, $\mathrm{H} 3, \mathrm{H} 4, \mathrm{H} 5, . \mathrm{H} 6$, and H7. However, a descriptive analysis on operators' profile was first conducted before inferential analysis in order to know the frequency and percentage of items in demographic profiles.

\section{A. Demographic Profile}

In term of gender, table 1 reveals that there are 40 from 60 persons $(66.7 \%)$ are female and only $20(33.3 \%)$ are male. In a context of education, this result also illustrates that some selected respondents $3.3 \%$ from the total respondents are never studied in primary education, there are only 7 respondents $(11.7 \%)$ are studied in primary school, and follow by SRP (18.3\%), SPM (35.0\%), STPM (16.7\%), diploma $(8.3 \%$ and degree $(6.7 \%)$. In term of age of operators, 2 operators $(3.3 \%)$ are those who below 20 years old, 8 operators $(13.3 \%)$ who are age in between $20-29$ years old, 17 operators $(28.3 \%)$ are those in between $30-39$ years old, there are 14 operators $(23.3 \%)$ who are 40 to 49 years old, follow by 15 operators $(25.5 \%)$ are those who are age in between $50-59$ years old, and lastly there are only 4 operators are above 60 years old $(6.7 \%)$

Furthermore, the length of period as homestay operator, there are 8 operators $(13.3 \%)$ who operating their business below 12 months, and follow by 18 operators $(30.0 \%)$ are operating within 13 - 24 months, 8 operators (13.3\%) operating their business within in both $25-36$ months and 37 - 48 months, 11 operators $(18.3 \%)$ who are operating within 49 - 60 months, and 7 operators (17.7\%) are operating homestay business above 61 months.

\section{B. Reliability Analysis}

As well as to study the consistency and stability of questionnaire, reliability becomes important in this study. The first run of test which administered on 60 respondents, yielded the cronbach alpha was read 9 variables in this study. It indicates the most of the variables that has been investigated in this study are found to be highly reliability as mentioned in table 1.

Table 1: The Alpha Cronbach's Value

\begin{tabular}{lcc}
\hline Dimensions & $\begin{array}{c}\text { No. of } \\
\text { Items }\end{array}$ & Alpha \\
\hline Government Support & 60 & 0.858 \\
Socio-economic & 35 & 0.916 \\
Local Leadership & 34 & 0.971 \\
Community Participation & 26 & 0.913 \\
Environment & 5 & 0.784 \\
Branding & 11 & 0.829 \\
Organizational Culture & 12 & 0.803 \\
Sustainable Development & 19 & 0.793 \\
\hline
\end{tabular}

\section{R Square}

In order to describe the relationship of community based tourism that affecting to the sustainability of homestay industry in Malaysia, the results indicates that the multiple correlation coefficient (R) which using all the predictors simultaneously is 0.756 and R-square is 0.572 which means that 57.2 percent of the variance in an integrate sustainable homestay in Malaysia can be predicted from the factors of community base tourism. Meanwhile, we noted that adjusted $\mathrm{R}$-square (0.515) is lower than the R-square (0.572) which is related to the number of variables in this study.

\section{Multiple Linear Regressions}

According to the table 5, there are only three out of four are significance toward the integrate sustainable homestay In fact, the multiple linear regressions analysis also produced standardized measures (Beta weight) on the strength of each dimension's association with the business commitment. Among the three independent variables of community base tourism, the factor of socio-economy (B $=.582, \mathrm{p}=.000$ ) was the main contributor that support the factor of integrated homestay sustainability. The factor of government support become the second contributor $(B=.266$, $\mathrm{p}=.015)$ and the factor of organization culture become as a third contributor in this study. Meanwhile, four other attributes concerning the local leadership, community participation, environment and branding are significant affecting to the integrate sustainable homestay

These findings also supported by previous literature including; Jenkins \& Oliver (2001), Oliver \& Jenkins (2003), Saxena et al. (2007), and Cawley \& Gillmor (2008), who claimed that the factors of government support, organizational culture and socio-economy in a community base tourism can be seen as underlying variables that are causally related to integrate sustainable homestay. Additionally, these findings also supported by the results of significance association the factors of socio-economy, organizational culture and government support toward integrating the homestay sustainability, as well as in hypothesis 1 , hypothesis 6 and hypothesis 7 .

\section{Conclusion and Recommendations}

In general, the objective of development of the homestay program in the rural areas is to increase the quality of life and to enhance the revenue among the local community. Then, the current issues of the homestay program now is how to sustain the homestay program in the future. As well as duscussed earlier, the objective of this paper is to study the various variables in a model of community based tourism as an influencing factor that affecting to the integrated sustainable homestay which are operating in Malaysia rural areas. Therefore, this paper analyses the relationship of seven independent variables and dependent variable. There are organizational culture, government support, local leadership, community participation, organizational capability, socio-economic, environment, 
branding(independent), business and integrate sustainable homestay (dependent variables). Thus the proposed conceptual framework of integrated sustainable homestay based on the previous literature and theoretical which are includes the inclusive variables such as organizational culture, branding, environment, socio economic, organizational capacity, community participation, local leadership and government support will create a new integrated indicators of sustainable homestay program in Malaysia.

The results gathered in this study showed that most of homestay operators in Malaysia are still not satisfying the important a numbers of factors in community based tourism that influencing in integrating the homestay sustainability. There are only the factor of socio-economy, organizational culture, and government support are satisfying by the homestay operators as well as to affect to their business sustainability. The findings in this paper also conclude that the operators are not really concern toward business suitability in homestay industry. Furthermore, the concept and model of Community based Tourism become crucial and practically applicable in developing an awareness and satisfaction among rural homestay operators toward the integrated of homestay sustainability. In fact, it also become crucial to the Malaysia government in constructing the policy regarding the community based tourism as well as to integrate the sustainability among homestay practitioners in rural areas.

\section{References}

[1] Aminudin, N., \& Jamal, S. A. (2006). Homestay Selangor: Keunikan dan pengalaman pengusaha. Pusat Penerbitan Universiti, Universiti Teknologi MARA.

[2] Baktygulov, S., \& Raeva, D. (2010). Creating value for all: Community-based tourism. Central Asia-Kyrgyzstan. New York: UNDP.

[3] Brida, J. G., \& Zapata, S. (2010). Cruise tourism: economic, sociocultural and environmental impacts. International Journal of Leisure and Tourism Marketing, 1(3), 205-226.

[4] Briedenhann, J., \& Wickens, E. (2004). Tourism routes as a tool for the economic development of rural areas-vibrant hope or impossible dream?.Tourism management, 25(1), 71-79.

[5] Cawley, M., \& Gillmor, D. A. (2008). Integrated rural tourism:: Concepts and Practice. Annals of Tourism Research, 35(2), 316-337.

[6] Chang, C.C., Jiang, J.P., \& Lan, C.H. (2009). Performance evaluation of homestay management in Gu-Keng area, Yunlin country. Journal of Statistics and Management Systems, 12:4, 651-669

[7] Goodwin, H. (2006). The Poverty Angle of Sun, Sea and SandMaximising Tourism's Contribution. In UNCTAD/WTO International Trade Centre Executive Forum Conference, September, Berlin.

[8] Hunter, C. (1995). On the need to re-conceptualise sustainable tourism development. Journal of Sustainable Tourism 3 (3), 155-65.

[9] Jenkins, T., \& Oliver, T. (2001). Integrated Tourism: A Conceptual Framework, Deliverable 1 SPRITE Project. Aberystwyth: Institute of Rural Studies.

[10] Lynch, P. A., McIntoch, A. J., \& Tucker, H. (2009). Commercial Homes in Tourism: An International Perspective. Routledge London \& New York.

[11] Mair, H. (2006). Global restructuring and local responses: Investigating rural tourism policy in two Canadian communities. Current Issues in Tourism, 9(1), 1-45.

[12] McMinn, S. (1997). The challenge of sustainable tourism. The Environmentalist,17 (2), 135-141. Meyer, J.L. and G.S. Helfman.
[13] Mitchell, R., \& P. Eagles (2001). An Integrative Approach to Tourism: Lessons from the Andes of Peru. Journal of Sustainable Tourism. 9:4-28.

[14] Miller, G (2003). Consumerism in sustainable tourism: a survey of UK consumers, Journal of Sustainable Tourism Vol 11 (1), 17-39.

[15] Murphy, P. E. (1985). Tourism: A community approach. New York: Methuen.

[16] Nine Malaysian Plan ,2006. Chapter 8 : Realising Tourism Potential. Malaysian Government.

[17] Oliver, T., \& Jenkins, T. (2003). Sustaining rural landscapes: The role of integrated tourism. Landscape Research, 28(3), 293-307.

[18] Razzaq, A. R. A., Mohamad, N. H., Kader, S. S. S. A., \& Mustafad, M. Z. (2013). Developing Human Capital for Rural Community Tourism: Using Experiential Learning Approach. Procedia-Social and Behavioral Sciences, 93, 1835-1839.

[19] Saarinen, J.,\& Lenao, M. (2014). Integrating tourism to rural development and planning in the developing world. Development Southern Africa, 31:3, 363-372

[20] Saxena, G., Clark, G., Oliver, T., \& Ilbery, B. (2007). Conceptualizing integrated rural tourism. Tourism Geographies, 9(4), 347-370.

[21] Saxena, G., \& Ilbery, B. (2010). Developing integrated rural tourism: Actor practices in the English/Welsh border. Journal of Rural Studies, 26(3), 260-271.

[22] Tourism Malaysia (2014). Tourism Malaysia Launches Year Of Festivals 2015, Retrieved on November 26th, 2014, from http://corporate.tourism.gov.my/mediacentre.asp? page=news_desk\&

[23] UNWTO (2015). Over 1.1 billion tourists travelled abroad in 2014 , Retrieved on February 5th, 2015, from http://media.unwto.org/pressrelease/2015-01-27/over-11-billion-tourists-travelled-abroad-2014

[24] Yusof, N., Said, I., Osman, Z., \& Daud, M. C. (2010). Are resort operators in the ecotourism area demanding an environmental protection culture? The case of Lake Kenyir, Malaysia. In 4th International Conference on Sustainable Tourism, Ashurst, New Forest, England, 5-7 July 2010. (pp. 183-193). WIT Press.

About Author (s):

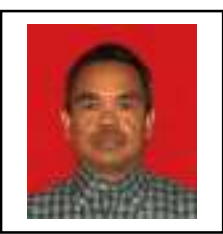

Name $\quad$ : Muhammad Abi Sofian bin Abdul Halim (Dr)

Department : School of Business and Maritime Management

Post : Senior Lecturer

Universiti Malaysia Terengganu

Qualification: $\mathrm{PhD}$ (Social Entrepreneurship)

Master of Business Administration

Bachelor of Music

Gender : Male

Race : Malay

Nationality: Malaysia

Address : PT26030, Jalan Tok Jembal, Kampung Kubang Badak, 21300, Kuala Terengganu, Terengganu

Handphone : 013-9204322 